\title{
KLASIFIKASI JALAN DI KAWASAN PERBATASAN NEGARA BERDASARKAN REGULASI TATA RUANG WILAYAH
}

\author{
Oleh:
}

\author{
FERDINAN NIKSON LIEM, SST., MT. \\ Staf Pengajar Teknik Sipil pada Politeknik Negeri Kupang \\ Jl. Adisucipto, Penfui - PO. BOX. 139 Kupang \\ ferdynikson@yahoo.co.id
}

\begin{abstract}
Abstrak
Infrastruktur jalan cukuplah penting dalam upaya pengembangan pembangunan untuk menjawab persoalan yang kemungkinan akan berdampak besar terhadap kesatuan Negara Indonesia dan bahkan hubungan dengan negara tetangga. Sebagai wilayah yang berbatasan darat dengan Negara Timor Leste, Kabupaten Belu dan Kabupaten Timor Tengah Utara serta Kabupaten Kupang di Provinsi NTT perlu dikaji klasifikasi jalannya agar dapat disesuaikan dengan regulasi tata ruang wilayah. Dari hasil analisis dapat disimpulkan bahwa beberapa ruas jalan baik jalan dengan status nasional, provinsi maupun kabupaten perlu dikaji dan disesuaikan kembali. Seluruh jalan nasional yang ditinjau pada prinsipnya sesuai dengan ketentuan yang ada, yaitu status jalan nasional dengan fungsi jalan arteri serta berdasarkan penggunaan ditetapkan menjadi jalan kelas I. Ruas jalan provinsi yang semula mempunyai fungsi kolektor ditingkatkan menjadi jalan dengan fungsi arteri dan status jalan strategis nasional serta berdasarkan penggunaan ditetapkan menjadi jalan kelas I. Sebagian ruas jalan kabupaten yang merupakan jalur menuju lokasi kawasan andalan yang semula mempunyai fungsi lokal mengalami peningkatan menjadi jalan kolektor dan status jalan tidak mengalami perubahan yaitu jalan kabupaten serta jalan kelas I.
\end{abstract}

\section{Pendahuluan}

Pada umumnya, permasa-lahan yang ada di kawasan per-batasan menurut The Partnership for Governance Reform dalam Partnership Policy Paper No. 2/2011, di antaranya adalah: 1) Perencanaan pembangunan wilayah perbatasan masih terkendala; 2) Kondisi masyarakat di kawasan perbatasan pada umumnya masih miskin, tertinggal, terbelakang, tingkat pendidikan dan kesehatan rendah, serta secara komunitas terisolir; 3) Lemahnya penegakan hukum, menyebabkan maraknya pelanggaran hukum di kawasan perbatasan. Implementasi pos-pos perbatasan dan fasilitasi bea cukai, imigrasi, dan karantina (CIQ/-Custom,
Imigration and Quarantina) tidak optimal dan terkendala banyak hal, sehingga mengakibatkan terjadinya berbagai kegiatan ilegal lintas

batas; 4) Belum sinkronnya pengelolaan kawasan perbatasan, baik menyangkut kelembagaan, program, maupun kejelasan wewenang; 5) Rentannya persoalan yang terkait dengan nasionalisme penduduk karena kurangnya informasi yang masuk dari Indonesia.

Sebagai wilayah yang berbatasan darat dengan Negara Timor Leste, Kabupaten Belu dan Kabupaten Timor Tengah Utara serta Kabupaten Kupang di Provinsi NTT masih memiliki kondisi yang menunjukkan gambaran yang ideal. Menurut The Partnership for Governance 
Reform, permasalahan mendasar yang dihadapi oleh masyarakat di kawasan perbatasan NTT ini di antaranya adalah: 1) Rendahnya tingkat kesejahteraan masyarakat di kawasan perbatasan; 2) Tidak memadainya sarana dan prasarana pendidikan, kesehatan, perhubungan, penerangan dan komunikasi, sehingga menyebabkan penduduk di kawasan perbatasan menjadi terisolir; 3) Ketertiban dan keamanan perbatasan masih menunjukkan dinamika yang tinggi.

Hal seperti tersebut di atas harus segera ditanggulangi sebelum menjadi persoalan yang berdampak besar terhadap kesatuan Negara Indonesia dan bahkan hubungan dengan negara tetangga. Karena itu, kawasan perbatasan negara yang merupakan pintu gerbang ke negara lain untuk memberi kesejahteraan bagi masyarakat di kawasan tersebut, tidak luput dari perhatian pemerintah dalam pengembangan infrastruktur.

Infrastruktur jalan cukuplah penting dalam upaya pengembangan pembangunan untuk menjawab hal-hal yang dikemukakan. Sebagai bagian prasarana transportasi darat sesuai Undang-Undang nomor 38 Tahun 2004 tentang Jalan, jalan mempunyai peran penting dalam bidang ekonomi, sosial budaya, lingkungan hidup, politik, pertahanan dan keamanan, serta dipergunakan untuk sebesar-besar kemakmuran rakyat. Pengelompokan (klasifikasi) jalan menjadi hal yang tidak bisa disepelehkan dalam proses tersebut dalam menjawab amanat peraturan perundang-undangan tentang jalan.

\section{Klasifikasi Jalan Umum}

Klasifikasi jalan umum menurut fungsi (UU No. 38 Tahun 2004) terbagi atas jalan arteri, jalan kolektor, jalan lokal, dan jalan lingkungan. Jalan Arteri merupakan jalan umum yang berfungsi melayani angkutan utama dengan ciri perjalanan jarak jauh, kecepatan rata-rata tinggi, dan jumlah jalan masuk dibatasi secara berdaya guna. Jalan kolektor adalah jalan umum yang berfungsi melayani angkutan pengumpul atau pembagi dengan ciri perjalanan jarak sedang, kecepatan rata-rata sedang, dan jumlah jalan masuk dibatasi. Jalan lokal merupakan jalan umum yang berfungsi melayani angkutan setempat dengan ciri perjalanan jarak dekat, kecepatan ratarata rendah, dan jumlah jalan masuk tidak dibatasi. Sedangkan jalan lingkungan adalah jalan umum yang berfungsi melayani angkutan lingkungan, ciri perjalanan jarak dekat, dan kecepatan rata -rata rendah.

Fungsi jalan arteri, kolektor, lokal dan jalan lingkungan yang terdapat pada sistem jaringan jalan primer dan sistem jaringan jalan sekunder dibedakan atas: (1) Jalan Arteri Primer yang menghubungkan secara berdaya guna antarpusat kegiatan nasional atau antara pusat kegiatan nasional (PKN) dengan pusat kegiatan wilayah (PKW), didesain berdasarkan kecepatan rencana paling rendah 60 kilometer per jam dengan lebar badan jalan paling sedikit 11 meter; (2) Jalan Kolektor Primer, menghubungkan secara berdaya guna antara PKN dengan pusat kegiatan lokal (PKL), antarpusat kegiatan wilayah, atau antara PKW dengan PKL, didesain berdasarkan kecepatan rencana paling rendah 40 kilometer per jam dengan lebar badan jalan paling sedikit 9 meter; (3) Jalan Lokal Primer, menghubungkan secara berdaya guna pusat kegiatan nasional dengan pusat kegiatan lingkungan, PKW dengan pusat kegiatan lingkungan, antar $\mathrm{PKL}$, atau $\mathrm{PKL}$ dengan pusat kegiatan lingkungan, serta antarpusat kegiatan lingkungan, didesain 
berdasarkan kecepatan ren-cana paling rendah 20 kilometer per jam dengan lebar badan jalan paling sedikit 7,5 meter; (4) Jalan Ling-kungan Primer menghubungkan antarpusat kegiatan di dalam kawasan perdesaan dan jalan di dalam lingkungan kawasan perdesaan, didesain berdasarkan kecepatan rencana paling rendah 15 kilometer per jam dengan lebar badan jalan paling sedikit 6,5 meter; (5) Jalan Arteri Sekunder menghubungkan kawasan primer dengan kawasan sekunder kesatu, kawasan sekunder kesatu dengan kawasan sekunder kesatu, atau kawasan sekunder kesatu dengan kawasan sekunder kedua, didesain berdasarkan kece-patan rencana paling rendah 30 kilometer per jam dengan lebar badan jalan paling sedikit 11 meter; (6) Jalan Kolektor Sekunder, menghubungkan kawasan sekunder kedua dengan kawasan sekunder kedua atau kawasan sekunder kedua dengan kawasan sekunder ketiga, didesain berdasarkan kecepatan rencana paling rendah 20 kilometer per jam dengan lebar badan jalan paling sedikit 9 meter; (7) Jalan Lokal Sekunder menghubungkan kawasan sekunder kesatu dengan perumahan, kawasan sekunder kedua dengan perumahan, kawasan sekunder ketiga dan seterusnya sampai ke perumahan, didesain berdasarkan kecepatan rencana paling rendah 10 kilometer per jam dengan lebar badan jalan paling sedikit 7,5 meter; (8) Jalan Lingkungan Sekunder, menghubungkan antarpersil dalam kawasan perkotaan, didesain berda -sarkan kecepatan rencana paling rendah 10 kilometer per jam, lebar badan jalan paling rendah 6,5 meter.

Yang dimaksud dengan "PKN", "PKW", dan "PKL" adalah kawasankawasan perkotaan yang masing-masing mempunyai jangkauan pelayanan berskala nasional, wilayah, dan lokal.
Makin tinggi hirarki suatu pusat kegiatan menggambarkan makin besar fungsi dan manfaat ruang pusat kegiatannya. Diagram keterkaitan antara fungsi jalan dengan fungsi kota yang dihubungkan berdasarkan fungsi (UU Nomor 38 tahun 2004 dan PP Nomor 34 tahun 2006) ditunjukkan dalam Gambar 1.

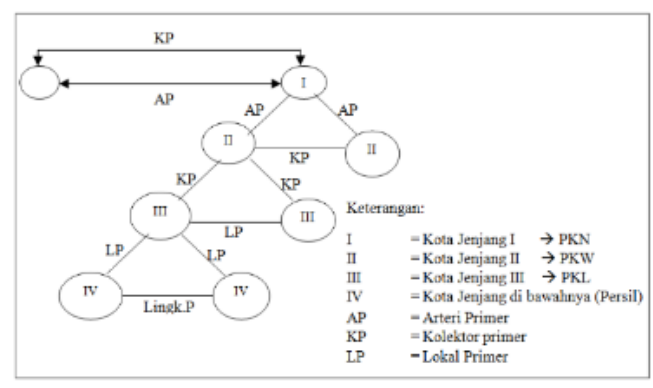

Gambar 1. Keterkaitan Antara Fungsi Jalan Dengan Fungsi Kota

Jalan umum menurut statusnya dikelompokkan ke dalam jalan nasional, jalan provinsi, jalan kabupaten, jalan kota, dan jalan desa. Menurut Undang-Undang (UU) Nomor 22 Tahun 2009, penetapan kelas jalan pada setiap ruas jalan dilakukan oleh: a) Pemerintah untuk jalan nasional; b) Pemerintah Provinsi untuk jalan provinsi; c) Pemerintah Kabupaten untuk jalan kabupaten; dan d) Pemerintah Kota untuk jalan kota.

Hubungan antara klasifikasi jalan dengan wewenang pembinaan dapat dilihat pada Tabel 1.

Tabel 1. Hubungan Antara Klasifikasi Jalan dengan Wewenang Pembinaan 


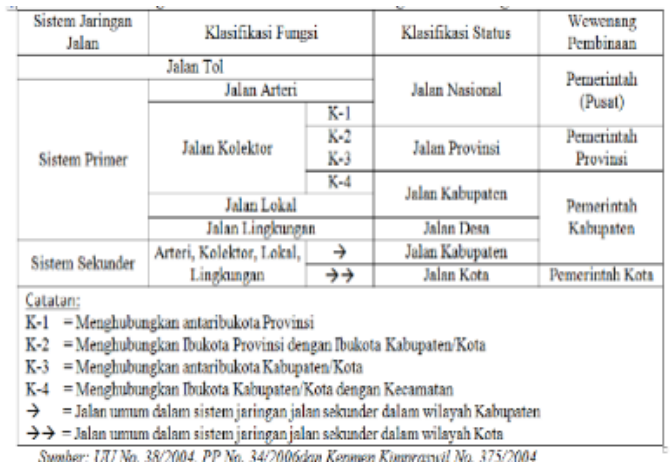

Klasifikasi menurut kelas jalan dan ketentuannya dapat dilihat dalam Tabel 2 (Pasal 19, UU.No.22/2009).

Tabel 2. Pengelompokkan Jalan Menurut Kelas Jalan dan Daya Dukung Menerima Muatan Sumbu dan Dimensi kendaraan Bermotor

\begin{tabular}{|c|c|c|c|c|}
\hline Kelas & Fungsi & \begin{tabular}{|c} 
Lebar \\
kendaraa \\
n maksi- \\
mum (m)
\end{tabular} & $\begin{array}{c}\text { Panjang } \\
\text { kendaraan } \\
\text { naksimum } \\
\text { (m) }\end{array}$ & \begin{tabular}{|c} 
Muatan \\
Sumbu \\
Terberat \\
MST (Ton)
\end{tabular} \\
\hline I & $\begin{array}{l}\text { Arteri } \\
\text { Kolektor }\end{array}$ & 2,5 & 18 & 10 \\
\hline II & $\begin{array}{c}\text { Arteri } \\
\text { Kolektor } \\
\text { Lokal } \\
\text { Lingkungan }\end{array}$ & 2,5 & 12 & 8 \\
\hline III & $\begin{array}{c}\text { Arteri } \\
\text { Kolektor } \\
\text { Lokal } \\
\text { Lingkungan }\end{array}$ & 2,1 & 9 & 8 \\
\hline Khusus & Arteri & 2,5 & 18 & $>10$ \\
\hline
\end{tabular}

Sumber :UU Nomor 22, 2009

Sedangkan menurut PP Nomor 34 Tahun 2006, fungsi jalan suatu ruas jalan dapat berubah apa-bila: (a) Berperan penting dalam pelayanan terhadap wilayah yang lebih luas daripada wilayah sebe-lumnya; (b) Semakin dibutuhkan masyarakat dalam rangka pengembangan sistem transportasi; (c) Lebih banyak melayani masyarakat dalam wilayah wewenang penyelenggara jalan yang baru; dan/atau (d) Oleh sebab-sebab tertentu menjadi berku-rang peranannya, dan/atau melayani wilayah yang lebih sempit dari wilayah sebelumnya.

\section{Jaringan Jalan berdasarkan Lingkungan dan Tata Ruang}

Salah satu arahan pemba-ngunan jangka panjang nasional tahun 2005-2025 seperti yang ter-cantum dalam Rencana Pemba-ngunan Jangka Panjang Nasional (RPJPN) adalah mengurangi kesenjangan antar wilayah yang merupakan perwujudan pembangunan yang merata ke seluruh wilayah. Untuk itulah arah dan kebijakan pemba-ngunan kewilayahan salah satunya akan dituangkan dalam arah pengembangan pulau-pulau besar, pengembangan wilayah laut dan pengembangan kawasan/antar kawasan. Arahan pengembangan kawasan/antar kawasan tersebut pada dasarnya merupakan salah satu upaya dalam mendukung percepatan pembangu-nan wilayah yang dapat dilakukan melalui: (1) Pengembangan kawasan strategis dan cepat tumbuh; (2) Pengembangan daerah tertinggal, kawasan perbatasan, dan rawan bencana; (3) Pengembangan kawasan perkotaan dan perdesaan; dan (4) Penataan dan pengelolaan pertanahan.

Pemerintah telah menetapkan 11 (sebelas) prioritas dalam Program Aksi Pembangunan Nasional 2010-2014, di mana dari 11 prioritas tersebut terdapat 8 (delapan) prioritas yang terkait dengan bidang pekerjaan umum dan penataan ruang seperti yang tercantum dalam Renstra Kementerian PU 2010-2014 yang meliputi: (1) Prioritas pembangunan 
infrastruktur; (2) Prioritas bidang kesehatan; (3) Prioritas penanggulangan kemiskinan; (4) Prioritas ketahanan pangan; (5) Prioritas pembangunan daerah tertinggal, terdepan, terluar, dan pasca konflik; (6) Prioritas reformasi birokrasi dan tata kelola pemerintahan; (7) Prioritas bidang lingkungan hidup dan pengelolaan bencana; dan (8) Prioritas iklim investasi dan iklim usaha.

\section{Terkait prioritas tersebut}

Kementerian PU melakukan dukungan terhadap peningkatan partumbuhan ekonomi dan kesejahteraan masyarakat yang dilaksanakan salah satunya melalui program-program pembangunan pembangunan infras-truktur untuk mengurangi kesenjangan anatar wilayah, dukungan terhadap kawasan perbatasan dan kawasan terpencil serta terisolir. Adapaun kebijakan pembangunan infrastruktur pekerjaan umum dan penataan ruang yang terkait dengan prioritas ke-5 tersebut adalah "pembangunan infrastruktur sesuai dengan arahan Rencana Tata Ruang Wilayah dan pembangunan berke-lanjutan di kawasan strategis, ter-tinggal, perbatasan, daerah terisolir untuk mengurangi kesenjangan wilayah, daerah rawan bencana, serta meningkatkan kualitas lingkungan perumahan dan permukiman dan cakupan pelayanan dasar bidang pekerjaan umum dan permukiman untuk mewujudkan kesejahteraan rakyat yang berkeadilan dan inklusif".

Dalam Peraturan Pemerintah Nomor 26 Tahun 2008 tentang Rencana Tata Ruang Wilayah Nasional (RTRWN) disebutkan bahwa pada dasarnya kawasan tertinggal dapat ditetapkan menjadi kawasan strategis nasional (dari sudut kepentingan pertumbuhan ekonomi) dan hal tersebut dilakukan dengan tujuan utama untuk dapat mempercepat pertumbuhan kawasan tertinggal. Selain itu dalam kebijakan RTRWN tersebut juga disebutkan bahwa pengembangan kawasan tertinggal dilakukan untuk mengu-rangi kesenjangan tingkat perkembangan antar kawasan. Sedangkan strategi-strategi pengembangan ka-wasan tertinggal yang ditetapkan di dalam RTRWN antara lain meliputi : Memanfaatkan sumber daya alam secara optimal dan berkelanjutan; Membuka akses dan mening-katkan aksesibilitas antara kawasan tertinggal dan puat pertumbuhan wilayah; (3) Mengembangkan prasa-rana dan sarana penunjang kegiatan ekonomi masyarakat; (4) Mening-katkan akses masyarakat ke sumber pembiayaan; dan

Meningkatkan kualitas dan kapasitas sumber daya manusia dalam pengelolaan kegiatan ekonomi.

Peran dari jalan harus mendukung tata guna lahan/tanah dari suatu kawasan secara efisien, dimana: (1) Jalan merupakan bagian dari sistem jaringan jalan yang tersusun dalam suatu tingkatan hirarki; (2) Sistem jaringan jalan merupakan bagian yang tak terpisahkan dari sistem transportasi di wilayah tersebut; (3) Sistem jaringan jalan dan tata guna lahan/tanah dari wilayah tersebut membentuk satu sistem transportasi dan tata guna lahan/tanah yang efisien. Menurut Undang-Undang Nomor 26 Tahun 2007, penataan ruang diklasifikasikan berdasarkan sistem, fungsi utama kawasan, wilayah administratif, kegiatan kawasan, dan nilai strategis kawasan. Jaringan jalan strategis nasional dikembangkan untuk menghubung-kan: (a) Antar-PKSN dalam satu kawasan perbatasan Negara; (b) Antara PKSN dan pusat kegiatan lainnya; dan (c) PKN dan/atau PKW dengan kawasan strategis nasional.

Hubungan Antara Simpul dan 
Fungsi Jalan / Jalan Strategis Nasional dalam Sistem Primer diperlihatkan dalam Tabel 3.

Tabel 3. Hubungan Antara Simpul dan Fungsi Jalan / Jalan Strategis Nasional dalam Sistem Primer

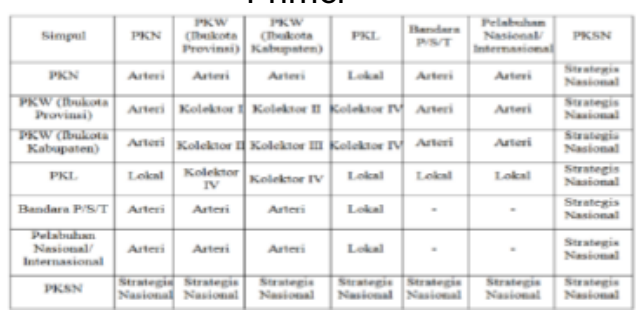

Sumber: PP No. 26 Tahun 2008

Kawasan Budi Daya yang memiliki nilai strategis nasional (Peraturan Pemerintah Nomor 26 Tahun 2008 Tentang Rencana Tata Ruang Nasional) adalah: kawasan peruntukan hutan produksi, kawasan peruntukan hutan rakyat, kawasan peruntukan pertanian, kawasan per-untukan perikanan, kawasan per-untukan pertambangan, kawasan peruntukan industri, kawasan perun-tukan pariwisata, kawasan perun-tukan permukiman; dan/atau kawa-san peruntukan lainnya. Kawasan budi daya sebagaimana dimaksud di atas ditetapkan sebagai kawasan andalan sedangkan nilai strategis nasional meliputi kemampuan kawa-san untuk memacu pertumbuhan eko-nomi kawasan dan wilayah di sekitarnya serta mendorong peme-rataan perkembangan wilayah.

Penetapan kawasan strategis nasional dilakukan berdasarkan kepentingan: (a) pertahanan dan keamanan; (b) pertumbuhan ekonomi; (c) sosial dan budaya; (d) penda-yagunaan sumber daya alam dan/atau teknologi tinggi; dan/atau (e) fungsi dan daya dukung lingkungan hidup.

\section{Prasarana Transportasi lainnya}

Keseluruhan jalan nasional yang berada di wilayah Pulau Timor diklasifikasikan secara fungsi sebagai jalan arteri primer sesuai Keputusan Menteri Pekerjaan Umum Nomor 360/KPTS/M/2009.

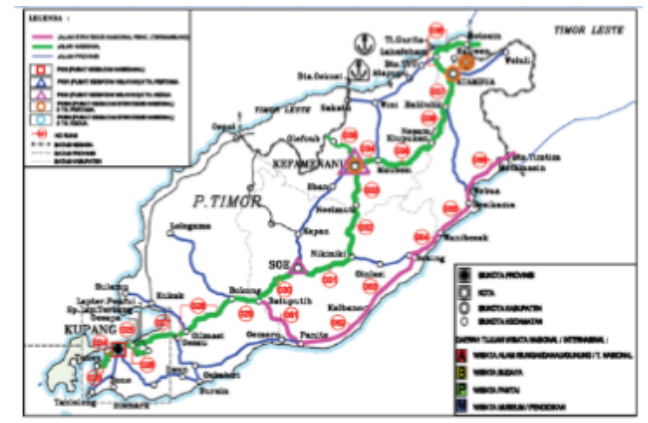

Gambar 2 Peta Jaringan Jalan di Pulau Timor

Sumber: P2JN, Kondisi 2013

Dalam RTRW Provinsi NTT, jalan arteri primer dengan status jalan nasional di Pulau Timor adalah: Bolok - Tenau; Jl. Ke Tenau (Kupang); JI. Tua Bata (Kupang); Jl. Pahlawan (Kupang); Jl. Soekarno (Kupang); Jl. A.Yani (Kupang); Jl. Siliwangi (Kupang); Jl. Sumba - Sumatera (Kupang); Jl. Timor - Timur (Kupang); Simpang Oesapa - Lap.Terbang Eltari; Jl. Raya Eltari; Oesapa - Oesao; Oesao Bokong; Bokong - Batuputih; Batuputih Bts Kota Soe; Jl. Gajahmada (Soe); Jl. Sudirman (Soe); Bts Kota Soe - Niki-niki; Jl. Diponegoro (Soe); JI. A. Yani (Soe); Niki -niki - Noelmuti; Noelmuti - Bts Kota Kefamenanu; Jl. Pattimura (Kefamenanu); Jl. Kartini (Kefamenanu); Jl.Eltari (Kefamenanu); Jl. Basuki Rahmat (Kefamenanu); Bts Kota Kefamenanu Maubesi; JI. A. Yani (Kefamenanu); Maubesi - Nesam (Kiupukan); Nesam (Kiupukan) - Halilulik; Halilulik - Bts Kota Atambua; JI. Suprapto (Atambua); JI. Supomo (Atambua); Jl. M.Yamin (Atambua); Jl. Basuki Rahmat (Atambua); Bts Kota Atambua - Motaain; Jl. 
Martadinata (Atambua); dan Jl.Yos Sudarso (Atambua). Sedangkan jalan kolektor primer (K1) yang berstatus nasional adalah Bts Kota Kefamenanu Oelfaub; Jl. Diponegoro (Kefamananu); JI. Sukarno (Kefamenanu); dan Jl. Ketumbar (Kefamenanu);

Jalan kolektor primer dengan status jalan provinsi di Pulau Timor meliputi ruas jalan: Oelmasi - Amarasi; Oelmasi - Sulamu - Amfoang Utara Oepoli; Takari - Amfoang Utara; Oepoli Eban - Kefamenanu; Batu Putih Amanuban Selatan; Amanuban Tengah Boking; Amanatun Selatan - Amanatun Utara; Soe - Mollo Utara; Kefamenanu Kapan; Kefamenanu - Wini - Biboki Anleu - Atapupu; Atambua - Lamaknen Haekesak; dan Malaka Tengah - Boking Kolbano - Amanuban Selatan - Amarasi - Kupang Barat (Selatan Timor).

Jaringan jalan perbatasan meliputi ruas jalan: Ruas jalan Wini - Maubesi Sakato - Wini - Atapupu; Ruas Mota'ain Atapupu - Atambua; Napan Kefamenanu; Motamasin - Halilulik; Haekesak - Atambua; Ba'a - Papela; Kalabahi - Taramana- Maritaing; Seba Bollow; dan Haumeni Ana - Soe.

Jaringan prasarana lalu lintas di Pulau Timor terdiri atas: Terminal Tipe A terdapat di Kabupaten Kupang; Terminal Tipe B terdapat di Soe di Kabupaten Timor Tengah Selatan, Kefamenanu di Kabupaten Timor Tengah Utara. Sedangkan rencana pengembangan terminal Tipe A terdapat di Mota'ain sebagai penghubung perbatasan antar negara disesuaikan dengan kapasitas pelayanan dan jumlah penumpang.

Penyeberangan lintas provinsi di Pulau Timor di antaranya adalah Pelabuhan Tenau di Kota Kupang. Penyeberangan lintas kabupaten/ kota, Pelabuhan Bolok di Kabupaten Kupang dan pelabuhan Teluk Gurita di Kabupaten
Belu.

Pelabuhan utama dalam tatanan kepelabuhan di NTT yaitu Pelabuhan Nusa Lontar - Tenau yang berfungsi sebagai jaringan trans-portasi laut internasional untuk pelayanan kapal penumpang, pari-wisata, ekspor, dan angkutan peti kemas ekspor-impor barang keraji-nan, seni, dan pelayanan sembilan bahan pokok. Sedangkan pelabuhan pengumpul di pulau Timor yaitu Pelabuhan Wini di Kabupaten Timor Tengah Utara dan Pelabuhan Ata-pupu di Kabupaten Belu, serta pelabuhan pengumpan di Pulau Timor yakni Pelabuhan Boking di kabupaten TTS dan Pelabuhan Naikliu di Kabupaten Kupang.

Alur pelayaran sebagaimana dimaksud pada RTRW Provinsi NTT 2010 - 2030 terdiri atas : (1) Alur pelayaran internasional meliputi jalur: Kupang Timor Leste; Atapupu - Timor Leste; dan Kalabahi - Timor Leste; (2) Alur pelayaran nasional meliputi jalur: Kupang - Lewoleba - Maumere - Makasar - Pare Pare Nunukan - Tarakan; Larantuka - Makasar - Batu Licin - Semarang - Tanjung Priuk - Tanjung Pinang; dan Ende - Waingapu Benoa - Surabaya - Dumai - Surabaya; (3) Alur pelayaran regional meliputi jalur: Kupang - Ndao - Sabu - Raijua - Ende Pulau Ende - Maumbawa - Mborong Waingapu - Waikelo - Labuan Bajo; Kupang - Naikliu - Wini - Kalabahi Maritaing - Lirang - Kisar - Leti; Kupang - Mananga - Lewoleba - Balauring Baranusa - Kalabahi - Atapupu; Kupang - Mananga - Maumere - Marapokot Reo - Labuan Bajo - Bima; Kupang Sabu Raijua - Raijua - Sabu Raijua Kupang; dan Kupang - Mananga Maumere - Sukun - Palue - Maurole Marapokot - Reo - Labuan Bajo - Bima.

Tatanan kebandarudaraan dalam sisitem transportasi udara terdiri atas: bandar udara pengumpul skala sekunder; 
bandar udara pengumpul skala tersier; dan bandar udara pengumpan. Bandar udara pengumpul skala sekunder di NTT yaitu Bandar Udara El Tari di Kota Kupang dengan penggunaan sebagai bandar udara internasional regional yang melayani rute penerbangan dalam negeri dan penerbangan luar negeri, serta berfungsi untuk kegiatan pertahanan dan keamanan di Kabupaten Kupang. Sementara itu, bandar udara pengumpul skala tersier terdiri atas: Bandar Udara Wai Oti (Frans Seda) di Kabupaten Sikka; Bandar Udara Mau Hau (Ir. Umbu Mehang Kunda) di Kabupaten Sumba Timur; Bandar Udara Hasan Aroeboesman di Kabupaten Ende; dan Bandar Udara Haliwen di Kabupaten Belu.

Sedangkan bandar udara pengumpan terdiri atas: b. Bandar Udara Lekunik di Kabupaten Belu; Bandar Udara Terdamu di Kabupaten Sabu Raijua; Bandar Udara Satartacik di Kabupaten Manggarai; Bandar Udara Mali di Kabupaten Alor; Bandar Udara Gewayantana di Kabupaten Flores Timur; Bandar Udara Wunopito di Kabupaten Lembata; Bandar Udara Soa di Kabupaten Ngada; dan Bandar Udara Komodo di Kabupaten Manggarai Barat.

\section{Analisis Hirarki Jalan}

Berdasarkan proyeksi penduduk hingga tahun 2020 maka kota-kota akan masuk dalam kategori kota sedang dan kecil dengan fungsi yaitu Kota Pusat Kegiatan Nasional (PKN), Kota Pusat Kegiatan Wilayah (PKW) dan Kota Pusat Kegiatan Lokal (PKL). Pengembangan sistem kota-kota di wilayah Provinsi Nusa Tenggara Timur dapat dilihat pada Tabel 4.

Tabel 4 Sistem Pengembangan Kota-Kota di Provinsi Nusa Tenggara Timur Tahun 2020

\begin{tabular}{|c|c|}
\hline Hierarki & Nama Kota \\
\hline $\begin{array}{c}\text { Kota } \\
\text { Hierarki । } \\
(\mathrm{PKN})\end{array}$ & \begin{tabular}{lr}
\multicolumn{1}{c}{ Kota } & Kupang, \\
Atambua, & Waingapu, \\
Labuanbajo & dan \\
Maumere. &
\end{tabular} \\
\hline $\begin{array}{c}\text { Kota } \\
\text { Hierarki II } \\
\text { (PKW) }\end{array}$ & $\begin{array}{l}\text { - Ibukota Kabupaten: Baa, } \\
\text { Soe, Kefamenanu, } \\
\text { Kalabahi, Lewoleba, } \\
\text { Larantuka, Ende, Bajawa, } \\
\text { Ruteng, Waikabubak } \\
\text { - Kota Kecamatan } \\
\text { Potensial: Betun, } \\
\text { Weitabula, Mbay/ } \\
\text { Aesesa }\end{array}$ \\
\hline $\begin{array}{c}\text { Kota } \\
\text { Hierarki III } \\
(P K L)\end{array}$ & $\begin{array}{c}\text { Ibukota-ibukota } \\
\text { Kecamatan lainnya }\end{array}$ \\
\hline alam & ran \\
\hline
\end{tabular}

Pemerintah Nomor 26 Tahun 2008 Tentang RTRWN, pemerintah telah menentukan kawasan-kawasan da-lam wilayah Indonesia yang men-cakup sistem perkotaan nasional, pelabuhan sebagai simpul trans-portasi laut nasional, badar udara sebagai simpul transportasi udara nasional, wilayah sungai, kawasan lindung nasional, kawasan andalan, dan kawasan strategis nasional. Kota, simpul, wilayah, dan kawasan tersebut juga mencakup wilayah NTT dan berkaitan dengan analisis dalam pembahasan ini, di antaranya:

- Kota Kupang ditetapkan sebagai PKN, Kota Soe dan Kefamenanu ditetapkan sebagai PKW (Kefamenanu dalam pengem-bangan baru menjadi PKSN), sedangkan Kota Atambua ditetapkan sebagai PKSN.

- Pelabuhan Tenau Kupang se-bagai simpul transportasi laut nasional ditetapkan sebagai pe-labuhan internasional yang se-dang dalam tahap pemantapan.

- Bandar Udara Eltari Kupang sebagai 
simpul transportasi udara nasional ditetapkan sebagai ban-dara udara sekunder, sedangkan Bandar Udara Haliwen Atambua dalam tahap pemantapan sebagai Bandar Udara Tersier.

- Wilayah Sungai (WS) Benanain dan WS Noelmina merupakan wilayah sungai Lintas Negara dengan Negara Timor Leste yang tahapan pengembangannya ada-lah konservasi sumber daya air, pendayagunaan SDA, dan pe-ngendalian daya rusak air.

- Untuk kawasan lindung nasional, Cagar Alam Gunung Mutis ditetapkan sebagai kawasan cagar alam dalam tahapan pengem-bangan pengelolaan kawasan lin-dung nasional, sedangkan Taman Buru Dataran Bena dalam tahapan pengembangan penge-lolaan kawasan taman buru nasional.

- Kawasan andalan untuk Kupang dan sekitarnya, sektor unggulan pertanian dalam tahapan pe-ngembangan kawasan andalan untuk pertanian, sektor industri dalam tahapan pengembangan kawasan andalan untuk industri pengolahan, sektor unggulan pariwisata dalam tahapan reha-bilitasi kawasan andalan untuk pariwisata, sektor unggulan peri-kanan laut dalam tahapan pe-ngembangan kawasan andalan untuk kelautan, sektor unggulan pertambangan dalam pengem-bangan kawasan andalan untuk pertambangan.

- Untuk kawasan strategis na-sional, Kawasan Perbatasan Darat RI dengan negara Timor Leste dan Kawasan Perbatasan Laut RI termasuk 5 pulau kecil terluar (Pulau Alor, Batek, Dana, Ndana, dan Mangudu) dengan negara Timor Leste/Australia termasuk dalam tahapan pengem-bangan/peningkatan kawasan strategis nasional dengan sudut kepentingan pertahanan dan keamanan.

Dalam Peraturan Daerah NTT Nomor 9 Tahun 2005 Tentang Rencana Tata Ruang Wilayah Provinsi (RTRWP) NTT Tahun 2006-2020 disebutkan bahwa jaringan jalan arteri primer meliputi bagian dari sistem jalan nasional yang menghubungkan ibukota propinsi dan/atau PKN yang melewati kota-kota ibukota kabu-paten dan kabupaten pemekaran, kawasan perbatasan negara dan kawasan strategis daerah. Jaringan jalan kolektor primer dengan status jalan provinsi meliputi jalan yang menghubungkan kawasan-kawasan strategis dalam pulau dan/atau antarkabupaten menuju ke jalan arteri primer atau arteri sekunder. Jaringan jalan lokal primer dengan status sebagai jalan kabupaten/kota meliputi jalan yang menghubungkan pusat-pusat pertumbuhan dalam pulau dan/atau antarkabupaten yang menuju ke jalan kolektor primer atau kolektor sekunder.

PKN, PKW, dan PKL dalam wilayah Provinsi NTT meliputi: Kota PKN, yaitu kota Kupang, Atambua, Waingapu, Labuan Bajo, dan kota Maumere; Kota PKW, yaitu kota-kota ibukota Kabupaten dan ibukota Kabupaten pemekaran serta ibukota kecamatan strategis; dan Kota $P K L$, yaitu meliputi seluruh kota ibukota kota kecamatan di Kabupaten. Hubungan Jaringan Jalan dengan Pusat Kegiatan secara relatif dapat digambarkan seperti pada Gambar 2.

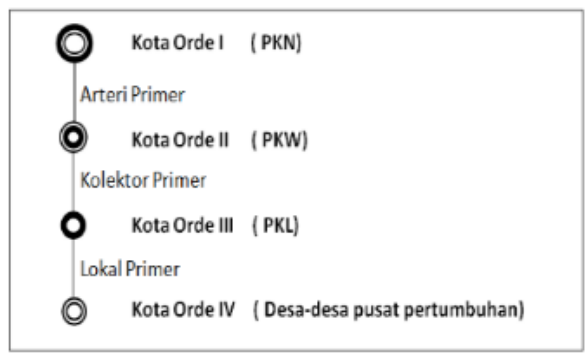

Sumber: RTRWPNTT, 2005 
Gambar 2. Hubungan Jaringan Jalan dengan Pusat Kegiatan

di Wilayah Nusa Tenggara Timur

Penentuan kelas jalan disesuaikan dengan UU Nomor 22 tahun 2009 tentang lalulintas dan angkutan jalan (Tabel 2), dimana penentuan kelas jalan tersebut berdasarkan kemampuan jalan untuk menerima beban lalulintas yang dinyatakan dalam Muatan Sumbu Terberat (MST) dalam satuan Ton. Oleh karena itu, dimensi kendaraan (lebar dan panjang kendaraan) juga dibatasi. Maka dalam analisis ini penyesuaian kelas jalan mengacu pada regulasi yang ada. Sesuai kondisi daerah dan kemampuan pembiayaan oleh pemerintah, seluruh ruas jalan yang ditinjau disesuaikan kelas jalannya paling tinggi yakni kelas I dengan fungsi arteri maupun kolektor.

\section{Penentuan Status, Fungsi dan Kelas Jalan}

Ruas jalan nasional pada saat ini dengan fungsi arteri primer yang melintasi wilayah kabupaten TTS dengan koridor jalan yang menghubungkan Pelabuhan Laut Tenau Kupang sebagai simpul transportasi laut nasional yang sesuai RTRWN ditetapkan sebagai pelabuhan internasional, melintasi Kota Kefamenanu (ibukota Kabupaten TTU) yang sedang dalam pengembangan baru menjadi Kawasan Strategis Nasional, dan berujung di Motoain (Atambua) sebagai Kawasan Perbatasan Darat RI dengan negara Timor Leste sebagai Kawasan Strategis Nasional. Hirarki jalan tersebut berdasarkan status dan fungsi jalan pada prinsipnya sesuai dengan kondisi yang ada dan regulasi tata ruang, sedangkan kelas ditetapkan sebagai jalan kelas I. Demikian pula ruas jalan nasional dengan fungsi kolektor (K1) ditetapkan kelas jalan adalah kelas I.

Ruas jalan provinsi yang secara fungsi diklasifikasikan sebagai jalan kolektor primer, secara keseluruhan sesuai Keputusan Gubernur Nusa Tenggara Timur tentang Penetapan Jaringan Lintas Angkutan Barang di Wilayah Daratan Timor adalah jalan dengan fungsi kolektor II dalam sistem jaringan jalan primer. Sesuai UndangUndang Nomor 38 Tahun 2004, Peraturan Pemerintah Nomor 34 Tahun 2006, dan Kepmen Kimpraswil Nomor 375 tahun 2004 serta RTRWN, maka hirarki ruas jalan yang saat ini berstatus jalan provinsi di NTT dapat disesuaikan.

Kawasan perbatasan laut dengan negara tetangga di bagian selatan Pulau Timor, kawasan yang dalam tahap pengembangan menjadi Taman Buru Nasional serta akses menuju kawasan pertambangan minyak bumi, menyebabkan ruas jalan menuju kawasan tersebut perlu disesuaikan dari jalan dengan status jalan provinsi menjadi jalan strategis nasional. Oleh karena itu, hirarki ruas jalan tersebut perlu ditingkatkan dari jalan provinsi menjadi jalan dengan status jalan strategis nasional.

Untuk ruas jalan lain yang saat ini berstatus jalan kabupaten yang terdiri dari koridor jalan yang menghubungkan kota kecamatan (PKL) dengan Pusat Kegiatan Lingkungan, maka berdasarkan tata ruang, secara fungsi diklasifikasikan menjadi jalan lokal primer, namun karena adanya kawasan peruntukan pertambangan yang memiliki nilai strategis nasional maka fungsi jalan ditingkatkan menjadi kolektor. Untuk mengakomodir lalulintas kendaraan tambang akibat dimensi dan berat kendaraan (MST), maka kelas jalan disesuaikan manjadi kelas I dan status jalan kabupaten.

Berkaitan dengan fungsi jalan seperti yang diatur dalam PP Nomor 34 
Tahun 2006 Tentang Jalan, maka penyesuaian hirarki untuk jalan yang ditinjau perlu disesuaikan juga mengenai lebar jalan minimum yang disyaratkan untuk masing-masing fungsi jalan. Dalam hal ini, untuk jalan arteri primer disyaratkan lebar badan jalan paling sedikit 11 meter, jalan kolektor primer dengan lebar badan jalan paling sedikit 9 meter, dan jalan lokal primer lebar badan jalan paling sedikit 7,5 meter.

\section{Kesimpulan}

Sesuai uraian dan hasil analisis di atas, maka disimpulkan bahwa:

a. Untuk saat ini klasifikasi jalan (status dan fungsi) perlu ditinjau dan dikaji agar sesuai dengan rencana tata ruang wilayah nasional, terutama jalan dengan status jalan provinsi yang merupakan koridor akses menuju kawasan strategis nasional dan kawasan budi daya serta kawasan lindung yang memiliki nilai strategis nasional. Kelas jalan berkaitan dengan kemampuan jalan untuk menerima beban lalulintas dan dimensi kendaraan pun harus sesuai dengan ketentuan regulasi yang ada, terutama jalan dengan status jalan provinsi dan jalan kabupaten. Sedangkan jalan dengan status jalan nasional pada prinsipnya sesuai dengan ketentuan yang ada berdasarkan klasifikasi menurut status, fungsi dan kelas jalan.

b. Hirarki jalan ditentukan sebagai berikut:

- Seluruh jalan nasional yang ditinjau pada prinsipnya sesuai dengan ketentuan yang ada, yaitu status jalan nasional dengan fungsi jalan arteri serta berdasarkan penggunaan ditetapkan menjadi jalan kelas I.

- Ruas jalan provinsi yang semula mempunyai fungsi kolektor ditingkatkan menjadi jalan dengan fungsi arteri dan status jalan strategis nasional serta berdasarkan penggunaan ditetapkan menjadi jalan kelas I.

- Sebagian ruas jalan kabu-paten yang merupakan jalur menuju lokasi kawasan anda-lan yang semula mempunyai fungsi lokal mengalami pe-ningkatan menjadi jalan kolektor dan status jalan tidak mengalami perubahan yaitu jalan kabupaten serta jalan kelas I.

c. Dengan adanya penyesuaian klasifikasi jalan ini diharapkan akan dapat menjadi salah satu langkah menjawab tujuan pem-bangunan nasional khususnya pengembangan kawasan perba-tasan sebagai pintu gerbang Negara tetangga, serta mewujudkan pembangunan untuk kesejahteraan masyarakat di ka-wasan perbatasan.

\section{DAFTAR PUSTAKA}

Gubernur Nusa Tenggara Timur, 2007, "Keputusan Gubernur Nusa Tenggara Timur", Nomor 339/KEP/HK/2007 Tentang Penetapan Ruas-Ruas Jalan Menurut Statusnya Sebagai Jalan Provinsi di Nusa Tenggara Timur, Pemerintah Provinsi Nusa Tenggara Timur, Kupang

Liem FN, 2011, Kesesuaian Hirarki Jalan Dan Kontribusi Biaya Pemeliharaan Jalan Dari Kendaraan Angkutan Tambang Mangan Di Kabupaten Timor Tengah Selatan, Tesis, 
Universitas Katolik Parahyangan, Bandung

Menteri Pekerjaan Umum, 2009, Keputusan Menteri Pekerjaan Umum Nomor 360/KPTS/M/2009 Tentang Penetapan Ruas-Ruas Jalan Dalam Jaringan Jalan Primer Menurut Perananannya Sebagai Jalan Arteri dan Jalan Kolektor 1, Departemen Pekerjaan Umum, Jakarta

Pemerintah Provinsi Nusa Tenggara Timur, 2005, "Rencana Tata Ruang Wilayah Provinsi Nusa Tenggara Timur 2006 - 2020', Badan Koordinasi Tata Ruang Daerah Provinsi NTT, Kupang

Pemerintah Provinsi Nusa Tenggara Timur, 2011, "Rencana Tata Ruang Wilayah Provinsi Nusa Tenggara Timur 2010 - 2030', Badan Koordinasi Tata Ruang Daerah Provinsi NTT, Kupang

Pemerintah Republik Indonesia, 2004, Undang-Undang Republik Indonesia Nomor 38 Tahun 2004 Tentang Jalan, Jakarta
Pemerintah Republik Indonesia, 2006, Peraturan Pemerintah Republik Indonesia Nomor 34 Tahun 2006 Tentang Jalan, Jakarta

Pemerintah Republik Indonesia, 2008, Peraturan Pemerintah Republik Indonesia Nomor 26 Tahun 2008 Tentang Rencana Tata Ruang Nasional, Jakarta

Pemerintah Republik Indonesia, 2009, Undang-Undang Republik Indonesia Nomor 22 Tahun 2009 Tentang Lalu Lintas dan Angkutan Jalan, Jakarta

P2JJ Dinas PU Provinsi NTT, 2010, "Data Kondisi Jalan Nasional Per 30 April 2010', Balai Pelaksana Jalan Nasional VIII Wilayah Kerja Provinsi Bali, NTB dan NTT, Kupang

Sarosa W, 2011, Kebijakan Pengelolaan Kawasan Perbatasan Indonesia, Partnership Policy Paper No. 2/2011, The Partnership for Governance Reform, Jakarta 
